\title{
Metal Ion Improved Properties of Burning Candle
}

\author{
Anthony P. Udoh, Aniekan U. Akpan, and Dominic J. Akpan
}

\section{ABSTRACT}

Irvingia gabonensis seed oil was extracted, characterized, and used in the production of metallic soaps of calcium, magnesium, and aluminium for application as hardeners for candle wax. The percentage free fatty acid (as oleic acid) is 2.76, the acid value is 5.50, unsaponifiable matter is 0.12 and the viscosity is $205.70 \times 102 \mathrm{Kgm}^{-1} \mathrm{~S}^{-1}$. The seed oil contains eight fatty acids; the most abundant being myristic acid with $54.39 \%$ followed by lauric acid with $36.83 \%$. The percentage saturated fatty acids (SFA), monounsaturated fatty acids (MUFA) and polyunsaturated fatty acids (PUFA) are 93.19\%, $6.27 \%$ and $0.54 \%$, respectively. The free fatty acid content of the soaps is in the order aluminium soap > magnesium soap > calcium soap. The metallic content of the soaps revealed that aluminium soap has the highest metallic content of $8.10 \%$ while that of calcium and magnesium soaps have $0.03 \%$ and $0.02 \%$ metallic contents, respectively. The melting points of the soaps prepared also followed a similar pattern. The aluminium soap exhibited mild acidic nature while calcium and magnesium soaps were basic. Although the lumens of the metallic soap candles were similar to that of local commercial candles which served as control, the candles had higher melting points and reduced burning rate. It is concluded from these that the metallic soaps make the candles harder and, longer lasting during burning and of greater value to the common user. Production of candles with metallic soaps as additives is highly advocated.

Keywords: candle, Irvingia gabonensis, metallic soaps, refined oil.

Published Online: October 13, 2021

ISSN: $2684-4478$

DOI : $10.24018 /$ ejchem.2021.2.4.77

\section{A. P. Udoh*}

Department of Chemistry, University of Uyo, Nigeria.

(e-mail:anthonypudoh@uniuyo.edu.ng)

A. U. Akpan

Department of Chemistry, University of Uyo, Nigeria.

(e-mail: aniekanuwemakpan3@gmail.com) D. J. Akpan

Department of Chemistry, University of Uyo, Nigeria.

(e-mail: dominicakpan838@gmail.com)

*Corresponding Author

\section{INTRODUCTION}

A candle is an ignitable wick embedded in wax or another flammable solid substance such as tallow, that provides light and, in some cases, a fragrance. A modern candle consists of two basic components. These are wax and wick. At room temperature, the wax is a solid substance that begins to melt when heated [1]. There are different types of wax including stearin, paraffin, vegetable wax, animal wax and gel wax [2]. The most common type of wax used in candle making process is petroleum-derived paraffin. Other specialty candles can be prepared from bees' wax, stearic acid, and clear gel [3].

Candles are not new in the society today. They are still widely adopted in numberless occasions to illuminate buildings or dark houses and to create a romantic environment due to their warms and pleasant sensationgiving emission which helps people to relax. They are also used in Churches for religious worship and in diabolic activities including rituals, decorations, festivals, and anniversaries. It is common to have candles on a birthday cake [4]. Candles derived from ancient torch, have a prolonged history of usage for the purpose of illuminating and this dates back to early civilization [5]. Scented candles play an important function in the health spas to relieve symptoms of chronchitis, high blood pressure, tension, insomnia and provide holistic approaches for relieving people of emotional and mental stress, grief, and trauma [6].

The desired properties of a burning candle include mostly long-lasting burning rate, enhanced illumination, nonsooting, and lack of odor unless it is intentionally scented [7]. Candles may burn with a flame of a characteristic color such as green, red, blue, orange or silver-white. The candles may be composed of a solvent, a hardener, and a metal salt dissolved in a solvent. The colored flame in the candle results from vaporized metal salts that travel up a wick with melted candle material [8]. The interactions of ionic species, precipitates and fine solids with a low energy hydrophobic surface using a model system of paraffin wax in aqueous solution were examined by [9]. They observed that metal ions had little affinity to paraffin wax and bubbles as anticipated for low energy.

Soywax was investigated by [10] for its tendency to produce soot as well as potentially harmful organic volatiles (acrolein, formaldehyde and acetaldehyde) during combustion, using paraffin and bees wax candles as references. A considerable amount of soot was produced from the combustion of paraffin candles while little or none was observed from soywax candles. Soywax candles burned at a significantly slower rate and required less air. It was observed by [14] that I. gabonensis seed oil showed low affinity for metallic soap production, and this was attributed to the high saturation of fatty acids. In the production of candles, a wick is located along the center of the candle. It is usually made of 
cotton, but paper wicks are also used. The principle of the wick is based on the capillary phenomenon [12]. The quality of the candle depends upon the nature of the wick and the combustible material (wax), and the building of the structure [13]. The quality of wax candle is improved by increasing the amount of stearic acid [14].

I. gabonensis is a species of African trees in the genus Irvingia, sometimes known by the common names wild mango, African mango, bush mango, dika, odika, òro, andok or ogbono, among different tribal groups. It is an evergreen tree and grows up to $30 \mathrm{~m}$ (98 ft.). The tree flowers once in a year. The flowers are pollinated by insects. The flowers develop into fruits; fruit maturation is observed when the green fruits turn yellow just like most other fruits. Although each part of the plant is useful, the seeds are the most important and sought-after part. This is because the fat content of the fruit has a very good aroma which makes it useful in soup preparation. The plant is very abundant in the rain forest zone of Nigeria.

The extraction of and characterization of the seed oil of $I$. gabonensis and the use of the oil in the preparation of metallic salts was described by [11]. They compared the properties of the soaps with metallic salts of other seed oils. This present work is on the application of the prepared metallic salts soaps to the preparation of candles and examination of the effects of the soaps on the performance characteristics of the candles. To our knowledge, there has not been a report of this nature before.

\section{MATERIALS AND METHODS}

\section{A. Sample Collection and Treatment}

Good fresh seeds of I. gabonensis were obtained from Obot Itu in Odukpani Local Government Area of Cross River State, Nigeria. The seeds were dried in the oven at $70{ }^{\circ} \mathrm{C}$ for 24 hours. The seed husk was removed, and the seed pulverized using a grinder. The pulverized seeds were wrapped in a polyethylene bag and kept in a desiccator.

\section{B. Extraction and Purification of the Oil}

The extraction and purification of oil were done according to [15]. In this procedure, the seed powder (300 g) was weighed and extracted with petroleum ether. The slurry obtained was stirred using a glass rod with more petroleum ether added until it overwhelmed the seed powder. After every four hours, the petroleum ether was decanted. The process was repeated with the addition of more petroleum ether to ensure complete extraction of the oil. The solution extract was distilled in order to separate the petroleum ether from the oil. The extracted oil was poured into an open beaker and heated in an oven at $70{ }^{\circ} \mathrm{C}$ for 24 hours to evaporate any water in the oil. The resultant oil in the beaker was covered with an aluminium foil and kept for further use. At room temperature, the oil is a solid and was melted every time it was to be used.

\section{Determination of the Fatty Acid Composition of the Seed Oil}

The fatty acid profile of the oil was determined by gas chromatography following the procedure presented by [16]. In this procedure, a round bottom flask was washed and dried in the oven. The oil sample $(0.8 \mathrm{~g})$ was placed in it and the flask, fitted with a condenser attached to a water tap was placed on an electro- thermal heater. The oil was refluxed for 3 hours using potassium hydroxide in methanol $(12 \mathrm{ml})$ to form the fatty acid methyl ester (FAME). After 1 hour, $\mathrm{HCl}$ $(2 \mathrm{ml})$ was added to break the fat in the sample. At the expiration of the remaining 2 hours, heating was stopped, and the flask was allowed to cool. N-hexane $(15 \mathrm{ml})$ was added to bring out all the fatty acids in the sample. Brine $(25 \mathrm{ml}$ of $25 \%$ solution) was added to separate the fat into layers. The mixture was stirred, shaken, and allowed to separate into layers and was labeled "ready for analysis". The gas chromatograph was connected to the inert gas supply. The line was evacuated for 2 minutes by turning on the vacuum pump simultaneously with the mains. A small quantity of the sample $(0.5 \mu \mathrm{l})$ was then introduced into the column through the sample port. A steady stream of the inert gas was passed through the column which was maintained at a definite temperature as directed in the user's manual. The eluent gas carried the vaporized components of the sample through the column. The recorder displayed the elution profile, and the peak areas were obtained. Analyses were based on peak areas.

\section{Preparation of Sodium Soap and the Calcium Magnesium and Aluminium Soaps}

The extracted fat $(50 \mathrm{~g})$ was heated to $90-95^{\circ} \mathrm{C}$ in a $500 \mathrm{~mL}$ beaker. Sodium hydroxide $(125 \mathrm{~mL}, 10.0 \mathrm{M})$ was added with frequent stirring for one hour to obtain the sodium soap which was separated from the lye. The soap was then washed with cold distilled water to remove excess alkali [17]. The metallic soaps of calcium, magnesium and aluminium were prepared as described by [11] from the sodium soap using the soluble salts of those metals $\left(\mathrm{CaCl}_{2}\right.$ for calcium, $\mathrm{MgSO}_{4}$ for magnesium and $\mathrm{Al}\left(\mathrm{NO}_{3}\right)_{2}$ for aluminium).

\section{E. Characterization of the Metallic Soap}

Determination of ash content, moisture content, free fatty acid, melting point, $\mathrm{pH}$, and appearance of the metallic soaps were done according to [16] while the determination of solubility of the metallic soaps was done according to the procedure presented by [18].

\section{F. Preparation of Candles}

Three different types of candles were produced using continuous molding method. To produce the candles, the wax was melted, and calcium soap produced was added (5\% of the total weight), the mixture was stirred until the metallic soap dissolved completely in the wax. The wax was then allowed to cool slightly above its melting point and poured into a prepared mold that had also been pre- heated. The mold was then placed in a bucket filled with water to speed up the solidification process. The candle production process was repeated with magnesium and aluminium soaps added to the wax. The same method was used to produce candles containing 50:50 w/w wax [19].

\section{G. Performance Test of Candles Produced}

The candles were characterized with respect to melting point, burning rate and lumen of light produced.

1) Determination of Melting point: Determination of melting point of the candles produced was done according to the procedure presented by [16]. 
2) Determination of Burning Rate: A ruler was used to mark $1 \mathrm{~cm}$ on each candle to be tested (up to $10 \mathrm{~cm}$ ). The time taken for each marked section of candle when it was lit to melt, or burn was measured. An average of all consecutive readings was calculated.

3) Measurement of the Lumen of Light: The lux meter was calibrated in a dark room, and its readings adjusted to zero. A table was placed in the middle of a dark room (at waist level of the experimenter), and a candle was placed on top of the table at the very edge and was then lit. The lux meter was placed one meter away from the light source and the lumen of the candle was measured. The measurement was done in all directions and the average reading recorded. This procedure was carried out for all the candles produced.

\section{RESUlTS AND DISCUSSION}

\section{A. Fatty Acids Composition of I. gabonensis Seed Oil}

The fatty acid profile of I. gabonensis seed oil is presented in Table I. Eight fatty acids are present in the oil; four of these are saturated acids.

TABLE I: FATTY ACIDS COMPOSITION OF I. GABONENSIS SEED OIL

\begin{tabular}{ccccc}
\hline Fatty acid & Name & $\begin{array}{c}\text { Composition } \\
\text { in the oil } \\
(\%)\end{array}$ & $\begin{array}{c}\text { Ester } \\
\text { (Triacyl- } \\
\text { glycerol) }\end{array}$ & $\begin{array}{c}\text { Classification } \\
\text { of the acid }\end{array}$ \\
\hline C10:0 & Capric & 1.15021 & Tricaprin & Saturated \\
C12:0 & Lauric & 36.82680 & Trilaurin & Saturated \\
C14:0 & Myristic & 54.38683 & Trimyristin & Saturated \\
C14:1 & Myristoleic & 4.92845 & Trimyristolein & Unsaturated \\
C18:0 & Stearic & 0.82940 & Tristearin & Saturated \\
C18:1 & Oleic & 1.33970 & Triolein & Unsaturated \\
C18:2 & Linoleic & 0.42690 & Trilinolein & Unsaturated \\
C18:3 & Linolenic & 0.11170 & Trilinolenin & Unsaturated \\
Total SFA & & $93.19 \%$ & & \\
MUFA & & $6.27 \%$ & & \\
PUFA & & $0.54 \%$ & & \\
Total UFA & & 6.81 & & \\
UFA/SFA & & 0.07 & & \\
\hline
\end{tabular}

The most abundant acid is myristc acid (C14:0) followed by lauric acid (C12:0) and an unsaturated acid, myristoleic acid (C14:1). From Table I, the saturated fatty acids however make up $93.19 \%$ of the total fatty acids. The major acids found (myristic acid C14:0, 54.38683 and lauric acid C12:0, 36.82680 ) are in agreement with previous reports by [20] and [21] although [22] obtained results which revealed that lauric acid was higher in content. According to [21], levels of components in plant systems and organs depend on the location of the plant. In comparison with other oils and fats, it is noted that I. gabonensis seed kernel oil is more saturated than conventional oils. This would make it a major food frying oil. The ratio of UFA to SFA is significant in animal feed formulations. However, [23] observed that variations in the ratio only had the potential to improve pork quality.

\section{B. Physicochemical Properties of the Prepared Metallic Soaps}

The physiochemical data on the metallic soaps are presented in Table II.

From the data in Table II, it can be deduced that the physical parameters of the sodium soap and other metallic soaps prepared are different. The melting points of the other metallic soaps are significantly higher than that of the sodium soap. This is due to the fact that melting point of the soap increased with increase in the relative atomic mass of the constituent metal in the soap and also the number of electrons a metal has available for bonding $\left(\mathrm{Al}^{3+}, \mathrm{Ca}^{2+}, \mathrm{Mg}^{2+}\right.$ and $\left.\mathrm{Na}^{+}\right)$. The melting points of the metallic soaps are in the order of $\mathrm{Al}$ $>\mathrm{Ca}>\mathrm{Mg}>\mathrm{Na}$ ). The $\mathrm{pH}$ values of the metallic soaps are in the order: $\mathrm{Na}>\mathrm{Mg}>\mathrm{Ca}>\mathrm{Al}(11.01>8.25-8.37>7.62$ $9.06>6.84-5.62$ ).

\section{Characteristics of the Prepared Candles}

The lumen of light of candles is affected by the width of the wick and the size of the candle. Each candle made was measured using a caliper and the width of each wick was ascertained to be of the same size and make. The data are presented in Table III.

TABLE III: DATA ON CANDLES PRODUCED WITH METALliC SOAPS AS ADDITIVES

\begin{tabular}{cccc}
\hline Candle type & $\begin{array}{c}\text { Melting } \\
\text { point range }\left({ }^{\circ} \mathrm{C}\right)\end{array}$ & $\begin{array}{c}\text { Burning rate } \\
\text { (Min :Sec:mSec/cm) }\end{array}$ & $\begin{array}{c}\text { Lux } \\
(\text { Lumen })\end{array}$ \\
\hline $\begin{array}{c}\text { Swan candle } \\
\text { (control, no }\end{array}$ & 56 & $9: 22_{59}$ & 12.1 \\
metallic soap) & & & \\
Aluminium (a) & $70-72$ & $15: 3_{22}$ & 12.0 \\
Aluminium (b) & $67-68$ & $14: 6_{12}$ & 11.9 \\
Calcium (a) & $67-69$ & $13: 1_{65}$ & 11.5 \\
Calcium (b) & $64-66$ & $12: 15_{12}$ & 11.4 \\
Magnesium (a) & $66-67$ & $12: 00_{28}$ & 11.7 \\
Magnesium (b) & $58-64$ & $11: 55_{25}$ & 11.6 \\
I. gabonensis (c) & 48 & $9: 12_{09}$ & 10.3 \\
\hline
\end{tabular}

(a): Candle made with metallic soap as additives and mixture of paraffin wax only.

(b): Candle made with metallic soap as additives and mixture of paraffin wax and I. gabonensis at 50:50 w/w.

(c): Candle made with only I. gabonensis oil as wax without metallic soap additive.

In all cases, the metallic soaps raised the melting point of the candles produced. The soaps made the candles harder and consequently to burn slower and last longer than the control. The lower melting point of the I. gabonensis lipid candle without any metallic salt additive corroborates the finding of [24] that the metallic soap increases the hardness of candles. This is confirmed by the burning rate values which are higher in all cases than the control. The I. gabonensis lipid candle without metallic salts additive possesses properties that are similar to those of the commercial candles which served as control.

\begin{tabular}{cccccccccc}
\multicolumn{8}{c}{ TABLE II: PHYSICOCHEMICAL PROPERTIES OF THE PREPARED METALLIC SOAPS } \\
\cline { 2 - 9 } & $\begin{array}{c}\text { Soap } \\
\text { metal }\end{array}$ & $\begin{array}{c}\text { FFA } \\
(\%)\end{array}$ & pH range & $\begin{array}{c}\text { Metal } \\
\text { content }(\%)\end{array}$ & $\begin{array}{c}\text { Moisture } \\
\text { content }(\%)\end{array}$ & M. p. $\left({ }^{\circ} \mathrm{C}\right)$ & $\begin{array}{c}\text { Total ash } \\
(\%)\end{array}$ & Color & Yield \\
\cline { 2 - 10 } & $\mathrm{Na}$ & 0.141 & 11.01 & $\mathrm{ND}$ & 53.60 & 110 & 25.13 & Milky white & High \\
$\mathrm{Al}$ & 10.55 & $5.62-6.84$ & 8.1025 & 89.54 & $178-198$ & 4.15 & White powder & High \\
$\mathrm{Ca}$ & 0.703 & $7.62-9.06$ & 0.03 & 3.58 & $118-120$ & 26.35 & White powder & High \\
$\mathrm{Mg}$ & 5.334 & $8.25-8.37$ & 0.02 & 90.08 & $100-115$ & 3.15 & White powder & High \\
\hline
\end{tabular}


Nigeria is a country where public supply of electricity is conventionally described as epileptic. On the average, there may be no electricity supply in 20 out of 24 hours of the day in many cities. Often times, power outage can last up to one week and beyond. There is usually resort to the use of alternative means and candle appears to be the cheapest alternative. The longer the burning of a particular candle, the more economical it is for the user. This observation is in line with chemical principles governing colligative properties of electrolytes that a dissolved substance or an impurity increases the boiling point of the solvent and the melting point of a solid. The melting points of the candles produced with the soaps as additives are high, making the candles harder and burning more slowly. This would help save cost in the purchase of candles especially the peasants in rural areas. There are various reports on metallic soaps, especially of stearates being used as driers, tablet formulants, lubricants and hardeners amongst others. The metallic soaps have little or no effect on the lux of the candles produced.

\section{CONCLUSION}

It is seen from the results that the metallic soaps have enhanced effect on the melting point and burning rate of the candles. This implies an easier and a more economic life for candle users. Commercial candle producers should consider incorporation of metallic soaps of sodium, aluminium, calcium, and magnesium in the production of candles. However, since I. gabonensis seeds are also used as soup thickeners and flavoring, increased cultivation of the plant is advocated to take care of this additional demand.

\section{REFERENCES}

[1] J. V. Anthony, P. Ramani, N. Anuja, H. J. Sherlin, S. Gheena, R. Abilasha, G. Jeyaraj, K. R. Don't, and S. Archana, "Impregnation and embedding using bees wax and paraffin wax in oral tissue samples: A comparative study," International Journal Orofac Biology, vol.1, pp. 13-15, 2017.

[2] Ministry of Environment and Food of Denmark, Survey and Risk Assessment of Particle and Heavy Metal Emissions from Candles; Town: Denish Environmental Protection Agency, 2017, pp. 14-15.

[3] A. Hamins, M. Bundy, and S. E. Dillon, "Characterization of candle flames," Journal of for Protection Engineering, vol. 15, no. 4, pp. 265 $285,2005$.

[4] J. Jou, C. Wu, Y. Su, Z. He, D. K. Dubev, and Y. Tsai, "Unveiling the mythical candles," Building and Environment, vol. 169, pp.106-565, 2020.

[5] T. Chen, X. Guo, and J. Xiao, "Frequency and phase characteristics of candle flame oscillation," Scientific Reports, vol. 9, p. 342, 2019.

[6] P. H. Danh, T. N. Pham, D. T. K. Nya, N. T. T. Nhung, T. D. Lam, and T. Q. Toan, "Preparation and characterization of naturally scented candles using the lemon grass (Cymbopogon citratus) Essential oil," Material Science Forum, vol. 977, pp. 212-217,2020.

[7] Danish Environmental Protection and Agency, Environmentally Friendly Candles with Reduced Particles Emissions; Denmark: Danish Technological Institute, 2018, pp. 3-5.

[8] J. S. Lesesne, "Lamp and candle with a coloured flame," United States Patent Application, 2002

[9] Z. A.Zhau, H. Hussein, Z. Xu, and J. Czarnnecke, "Interaction of ionic species and fine solids with a low energy hydrophobic surface from contact angle measurement," Journal of Colloid and Interface Science, vol. 204, no.2, pp. 342-349, 1998.

[10] K. Rezaii, T. Wang, and and L. A. Johnson, "Hydrogenated Vegetable oils and candle wax," Journal of the American Oil Chemists' Society, vol. 79, pp. 803-808, 2002.

[11] E. A. Essien, A. U. Akpan, U. I. Etim, and I. U. Udoekpo, "Oil Extraction from Edible oil seeds; Irvingia gabonensis, Citrullus lanatus and Telferia occidentalis and evaluation in metallic soap preparation,'
International Research Journal of Pure and Applied Chemistry, vol. 6, no. 2, pp. 95-104, 2015.

[12] K. Balog, H. Kobeticova, and T. Stefko, "Flammability Parameters of Candles, Research Papers, Faculty of Material Science and Technology, Trnava Slovak University of Technology in Bratislava, 2017.

[13] J. Wisniak, “Candle: A light into the past," Indian Journal of Chemical Technology, vol. 7, pp. 319-326, 2001.

[14] K. B. Sharma, Industrial Chemistry Including Chemical Engineering, 15th ed. Meerut: GEOL Publishing House, p. 1239, 2006.

[15] M. B. Jacobs, The Chemical Analysis of Food Products, 3rd ed. New Delhi: CBS Publishers and Distributors, pp. 365-385, 1999.

[16] AOAC, Official Methods of Analysis of the Association of Official Analytical Chemists, Washington DC: AOAC Inc., pp. 503-533, 2015.

[17] O. Ekpa, and U. J. Ibok, "Simple method for producing adhesives from Hevea brasiliensis," Tropical Journal of Applied Sciences, vol. 1 no.1, pp. 54-55, 1991.

[18] M. B. Dalen, and P. A. Mamza, "Some physicochemical properties of prepared metallic soap-driers of aluminium, copper and zinc," Science World Journal, vol. 4, no. 3, pp. 7-9, 2009.

[19] C. David, Candle Making, Schwartz: Arthur and Co., pp. 1-6, 1993.

[20] H. M. Womini, R. Ndjouenkeu, C. Kapseu, F. T. Mbiapo, M Parmentier, and J. Fanni, "Aqueous Enzymatic oil extraction from Irvingia gabonensis seed kernels," Proceedings of the 4th Euro. Fed. Lipid Congress - Fat, Oils and Lipids for a Healthier Future, eds. A. Lesley, and B. Nick, pp. 20-26, Madrid, 2006.

[21] L. Matos, J. M. Nzikou, E. Matouba, V. N. Pandzou-Yembe, T. G. Mapepoulou, M. Luider, and S. Desobry, "Studies of Irvingia gabonensis seed kernels: Oil technological application," Pakistan Journal of Nutrition, vol. 8, no. 2, pp. 151-157, 2009.

[22] O. U.Njoku, and J. O. Ugwuanyi, "Nutritional and toxicological properties of Dika fat (Irvingia gabonensis)," Journal of Herbs, Spices and Medical Plants, vol. 4, no. 4, pp. 53-58, 1997.

[23] W. Tartrakoon, T. Tartrakoon, and N. Kitsupree, "Effects of ratio of unsaturated fatty acid to saturated fatty acid on the growth performance, carcass and meat quality of finishing pigs," Animal Nutrition, vol. 4, no. 2, pp. 79-85, 2016.

[24] O. Ekpa, Entrepreneurship Chemistry: A Chemist's Approach to Wealth Creation in a Depressed Economy, The 4th University of Calabar Inaugural Lecture, Calabar, pp. 28-58, 2009.

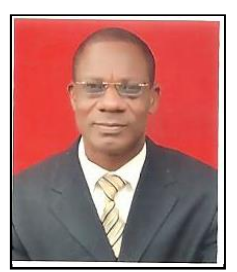

Anthony P. Udoh was born on January 03, 1954 at Afaha Esang, Afaha Obong in Abak Local Government Area of Akwa Ibom State, Nigeria. Udoh attended the St. Peter Catholic School, Adiasim in Essien Udim Local Government Area of Akwa Ibom State, Nigeria and obtained his secondary education at the Queen of Apostles Seminary, Afaha Obong, Abak LGA of Akwa Ibom State, Nigeria. He attended the Ahmadu Bello University Zaria, at different times and obtained the following degrees: B. Ed. (Science Education) in 1980, M. Sc. (Analytical Chemistry) in 1983, and Ph. D (Analytical Chemistry) in 1990.

$\mathrm{He}$ joined the chemistry teaching crew of the then College of Education, Uyo, Nigeria which metamorphosed into the University of Cross River State, Uyo, and later, the University of Uyo. Currently, he is a lecturer in general and analytical chemistry at the Department of Chemistry, University of Uyo, Uyo, Akwa Ibom State. He has published in the areas of analytical chemistry, environmental chemistry, food and oil analyses and corrosion studies. Currently, he is interested in wastewater treatment with carbon.

Prof. Udoh is an Associate Member of the Royal Society of Chemistry, the Science Association of Nigeria and the American Chemical Society.

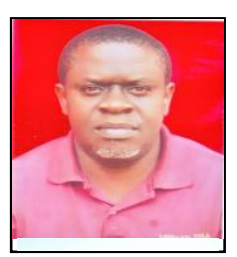

Aniekan U. Akpan was born on May 20, 1976, at Ikot Ebre Nsit in Nsit Ibom Local Government Area of Akwa Ibom State Nigeria. Akpan attended Government Primary School, Ikot Nya in Nsit Ubium LGA of Akwa Ibom State, Nigeria and had his secondary education at Government Secondary School, North Bank, Makurdi in Benue State of Nigeria. Mr. Akpan attended the College of Education, Afaha Nsit in Nsit Ubium Local Government Area of Akwa Ibom State where he obtained the Nigeria Certificate in Education (N. C. E.) and majored in Chemistry and Integrated Science as his teaching subjects in 1994. He also obtained a Diploma in Computer Science from the same institution in 1998. He attended the University of Uyo at different times and obtained the following qualificaions: National Diploma (ND) in Science Laboratory Technology in 2005 and Bachelor 
of Science (B.Sc.) degree in Pure Chemistry in 2007. He also attended the University of Calabar and obtained the Higher National Diploma in Science Laboratory Technology in 2010.

$\mathrm{He}$ has served as a technologist at the School of Basic Studies, University of Uyo, Uyo, and is currently a Senior Technologist at the Centre for Biomedical Research, University of Uyo. He did this research as a part of the requirements for a Master of Science degree in analytical Chemistry under my supervision.

Mr. Akpan is a registered teacher with the Teacher Registration Council of Nigeria. He is also a certified technologist with the Nigerian Institute of Science Laboratory Technology.

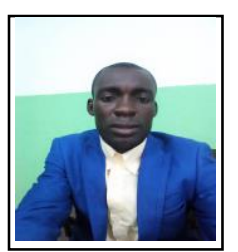

Dominic J. Akpan was born on March 29, 1985, at St Luke Hospital, Anua Offot, in Uyo Local Government area of Akwa Ibom State. Akpan attended the University of Uyo, Uyo at different times and obtained his B. Sc. Chemistry and M. Sc. in Analytical Chemistry degrees in 2009 and 2021, respectively.

$\mathrm{He}$ is a high school chemistry teacher at the Ray-field International Secondary School, Uyo, Akwa Ibom State and had at one time served as the Head of Science Department in that school from 2014 to 2017. He drafted the manuscript from the original writeup. 